\title{
Normativity of Scientific Law in the Perspective of Neo-Kantian Schools of Thought
}

\author{
FX. Adji Samekto \\ Faculty of Law, Diponegoro University \\ Jln. Prof. Soedarto, SH. Kampus Undip, Tembalang, Semarang, Indonesia \\ Tel./Fax:+62-24-76918206E-mail: adjisamekto@yahoo.com \\ Ani Purwanti \\ Faculty of Law, Diponegoro University \\ Jln. Prof. Soedarto, SH. Kampus Undip, Tembalang, Semarang, Indonesia \\ Tel./Fax: +62-24-76918206 E-mail:ani_purwanti81@yahoo.com
}

Submitted: Jan 17, 2017; Reviewed: Mar 24, 2017; Accepted: Mar 28, 2017

\begin{abstract}
Scientific normativity of law conceived as a character inherent in legal science as a sui generis. Jurisprudence basically studies the law, something that initially emerged from the dogmatic belief in philosophy. Dogmatism refuse to alter beliefs one iota. The teachings of dogmatic philosophy stem from the teachings of Plato and reflected in the legal enforceability. Dogmatism in the law is reflected in the Corpus Juris Civilis. Along with the development of post Era Scholastic philosophical thinking, the philosophy synthesizes thought between dogmatic thinking and skeptic has appeared in the Age of Enlightenment. This idea is reflected in Transcendental Idealist philosophy thought of Immanuel Kant. The core idea is that real human beings are given the ability to understand based on empirical experience and actually also able to gain an understanding of the human being that is the essence of symptoms. Transcendental Idealist, thus dynamic, moving to look for values that are useful for life. Transcendental Idealist thought then be adopted Kelsen in the teaching of normativity in legal positivism. Normativity in the teachings of Hans Kelsen's legal positivism derived from the integration of empirical positivism and idealistic empiricism.
\end{abstract}

Keywords: Hans Kelsen; Neo-Kantianism; Normativity; Transcendental Idealist

DOI: 10.20956/halrev.v3i1.761

\section{INTRODUCTION}

Normativity, in this issue is discussed in the context of legal normativity. Normativity of law refers to the state of the fulfillment of several requirements to achieve the sense that the law has been normative. Normative terminology comes from the word norm which in this paper is conceived as a set of instructions, orders or guide what should and should not do. Norm thus not be natura because it does not just happen, but is born from the value options that originates in dialectic of human thought. In jurisprudence language, norms are das sollen (supposedly). It is because the norm is based on values that is required, while the values are the result of the dialectic of human thought and then agreed as the values that will be elaborated 
in the form of a basic norm (grundnorm). Furthermore, this basic norm that serves as the source of necessity (natural reign source) of the law. Natural reign of law can only be fulfilled if the law meets the following requirements: (1) the law is derived from the norms that have been agreed (2) these norm is something that has been objectified so that becomes subjectivity shared by the makers of the norm itself i.e. the public. Discussion of how to position the norm in this law, can not be separated from the thought of Hans Kelsen.

Jurisprudence, can be explained in two different categories: Firstly, as a normative study which the object is the legal system is conceived as a collection of positive norms in public life. Research is to find out the legal principles that should apply and vice versa. The study of law in this category is the professional studies that provide skills, mastery in decision making, control to decide who is wrong and who is right in a case. Secondly, the science of law can be seen as a scientific study that intends to searching and revealing the truth. In this second category of legal study intends to explain, criticize, and then construct a new provision or theory building.

In teaching the science of law, often "mistaken", which puts the legal doctrine is identical to the philosophy of positivism. Positive law is identified as a derivative of a whole philosophy of positivism. Whereas if the assessed real, development of the science of law in the reasoning positivism thought has dialectical developmet from logical positivism of John Austin headed idealisticpositivism of Hans Kelsen.
Legal studies, in fact very closely related to the philosophy and teachings of the law from time to time that dialectically affect each other. The effects of natural law in the era of Plato, then the scholastic era, then the era of rationalism and the influence of the philosophy of positivism in science are very attached to the normative legal study to date. ${ }^{1}$ Therefore, not only the philosophy of positivism that influence the development of legal studies. Based on that, the study of normative law actually has a characteristic that is different from the social sciences. If the social sciences are developed based on the philosophy of positivism, the doctrine of law is not fully developed based on the philosophy of positivism. ${ }^{2}$ Not all logical positivism philosophy can be applied within the law.

This paper is motivated by the desire to awaken to the reviewer of jurisprudence, that actually learning about normativity in the science of law can be addressed in a variety of approaches. A good understanding of a variety of approaches in the science of law will certainly realize that nothing can be considered the truest and the most perfect approaches. All are complementary, and it is very useful for the development of the science of law to achieve the goals of the law itself. This paper focuses the discussion of normativity of law in the perspective of Kantian philosophical school of thought, a school of philosophy that grew in Germany in the early nineteenth century, which was then at the beginning of the XX century was

Catherine Kellogg. (1998). "The Messianic without Marxism: Derrida's Marx and the Question of Justice". Journal Cultural Values, 2(1): 51-69. Doi: http://dx.doi. org/10.1080/14797589809359287

Paulson, S. L. (1992). "The Neo-Kantian Dimension of Kelsen's Pure Theory of Law". Oxford Journal of Legal Studies, 12(3), 311-332. 
corrected by a group of Neo-Kantian. The chosen of philosophical school of thought by Immanuel Kant to discuss normativity in the science of law because, this school of thought affect the great thinkers in the science of law, namely: Hans Kelsen (from 1881 to 1973$)$.

Legal reasoning in this paper is based on the positive-philosophy, which conceived of the rule of law as the highest authority containing orders and sanctions. Selection of the legal reasoning based on the philosophy of positivism in this paper is motivated by the belief that the search of normativity would be very understandable if the law traced from dialectics that eventually gave birth to idealistic-positivism of Hans Kelsen.

\section{ANALYSIS AND DISCUSSION}

Thought of Neo-Kantian and Forming

\section{Norms}

Neo-Kantian thought is a school of philosophy that grew at the beginning of XX century. It has been known that in the early twentieth century some of the philosophical schools revived philosophical systems of the nineteenth century such as Idealist Dialectic philosophy of Georg Willem Friedrick Hegel and also Transcendental Idealist philosophy of Immanuel Kant (1724-1804). Neo-Kantian philosophical thought, thus sourced from Transcendental idealist philosophy of Immanuel Kant. Kantian thought in this paper refers to the notion of philosophy that was initiated by the German philosopher Immanuel Kant who gave birth to the philosophy of transcendental idealist ${ }^{3}$ which is

\footnotetext{
Immanuel Kant (1724-1804) was born in Konigsberg is a Professor in the town. At first the thought of Immanuel Kant was influenced by Leibniz, a Rationalist very
}

then written in his work: (1) Critique of Pure Reason, (2) Critique of Practical Reason and in 1790: (3) Critique of Judgement ${ }^{4}$.

The worldview of Immanuel Kant actually departed from the naturalism philosophy of Plato and Aristotle, but the dialectic that built, combine it with a view sourced from rationalism. In the way of thinking philosophy of Plato and Aristotle, the real life of the universe provides ideal life (the life of the spirit, an abstract containing absolute truths) and natural facts (ie everyday fact of life that just happens). Ideal world contains truths incontrovertible, because there dwells the highest ideal that govern the universe. For Plato and Aristotle, lives in a world of fact had to be regulated and restricted by law (teachings) which were born from the natural ideal (ideos). Man in the world of facts, not allowed to come out of the teachings of this a priori. Thus, in the thinking of Plato and Aristotle, the human mind only portrays the world. No more than that.

In contrast to Plato, Aristotle, Plato's student prefers the movement, the process becomes. Differing views of Plato and Aristotle: Plato taught that the universe consists of two (2) worlds, the world of phenomena (the object of experience, facts) and the world Ideos (object definition). The world of phenomenal and the world ideos are apart. For Aristotle, there's no separatation between the phenomenal world and the

systematic and influential in Germany. But after reading the thoughts of David Hume, his thinking changed $t$ all. Richard Osborne. (1991). Philosophy for Beginners, (Translated by: P. Hardono Hadi). Yogyakarta; Kanisius, p. 101-106; Theo Huijbers. (1982). Filsafat Hukum Dalam Lintasan Sejarah. Yogyakarta: Kanisius, p. 94-102.

4 Richard Osborne, Ibid, p. 101-106; Theo Huijbers, Loc. Cit 
world ideos.

Based on the views of Plato and Aristotle, Immanuel Kant then built a philosophy that combined naturalist-idealist (sourced from Plato and Aristotle) and empiricism thought sourced from Francis Bacon (1561-1626). Empiricism means that all knowledge comes from experience ( $a$ posteriori). Empiricism was born in the Age of Enlightenment as the reaction of distrust against the thoughts of Platonian Era and Scholastics Era that based only on mere belief or faith. For adherents of empiricism, thoughts that are born in an earlier era (Platonian and scholastic) are considered speculative.

The starting point of the Age of Enlightenment was marked by evidence of the truth of the proposition-Copernicus about the sun which is actually the center of the universe, not the earth just as convinced by the clergy during that era. Empiricism can not be removed from the teachings of Francis Bacon. Francis Bacon was an outspoken critic of the teachings of scholastic Era. Francis Bacon taught about the importance of the science and the use of ratios to improve the lives of humans. In developing the knowledge of the phenomenon (the fact) Francis Bacon gives strong emphasis on experimentation and observation. He is known for his motto: "knowledge is power".

The teachings from Immanuel Kant are known as Transcendental Idealist philosophy, that is actually a reaction against Positivism.

\footnotetext{
Francis Bacon. (1958). The Advancement of Learning, (last reprinted), London: J.M Dent and Sons Ltd; Richard Osborne, p. 67-68; Paul Kleinman. (2013). Philosophy 101 From Plato and Socrates to Ethics and Metaphysics, an Essential Primer on the History of Thought, Massachuset: Adam Media, p. 36-44.
}

Philosophy thought of Immanuel Kant is a picture of the widespread dissatisfaction with the positivism, because positivism is not always able to answer the questions of human life. Easily, the difference between the philosophy thought of Immanuel Kant with positivism can be simplified in the following matrix:

\section{Positivism \\ Rejecting the notion that human are able to achieve an understanding of the phenomenon of life in any metaphysical or essence.}

\section{Kantianisme}

Defended the view that human actually are able to gain an understanding of the phenomenon of life in any metaphysical or essence.

Immanuel Kant built philosophy by combining naturalist-idealist thinking and empirical thought. In the teachings of Kant, human knowledge is divided into a knowledge-based on facts (das sein) and knowledge of the practical reason that concerns the nature of life das sollen. Each is described as follows:

First, the field of knowledge-based on facts (das sein) is referred to as theoretical knowledge. This knowledge based on observations which were born through sensory experience. Hence, the so-called theoretical knowledge in the conception of Kant's philosophy is the knowledge of something concrete, at a certain time and in certain situations. However, according to Kant, knowledge can be subjective, meaning that each person can be different.

Second, the field of knowledge of practical reason, the knowledge aspect of human life which is das sollen. Here there is subjectivity, because every human being has the subjectivity of thinking about actions that can and can not do. For example, humans 
may attempt to kill another human being in order to survive life. But it was not done, because there are basic principles that apply to humans. This principle is not derived from experience, but from the transcendental ideas, which eventually gave birth to the basic principles ${ }^{6}$. The basic principles that is then analyzed will reduce the norm. That's the philosophy of Immanuel Kant's system was built in XIX century. Below is presented the thought of Immanuel Kant in the following picture:

\section{Illustration of Transcendental Idealist Philosophy of Immanuel Kant}

Rationale: Man is the center and subject of creativity. Man is not merely describe the world, but also can change the world by reason and ratio.

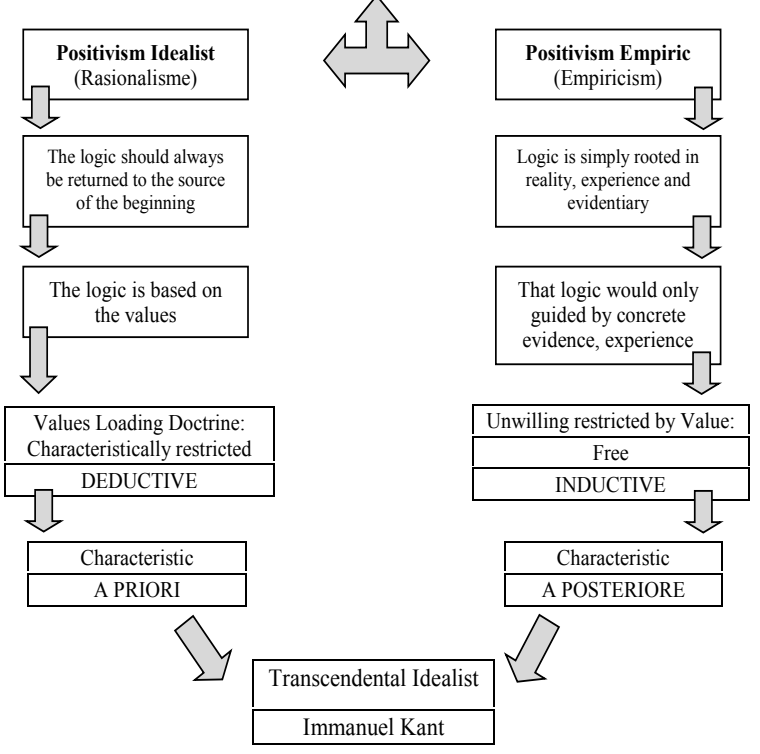

Transcendental Idealist Philosophy departs from the premise that man is the center and subject of creativity is not just describe that happens in the world, but also change the world. With this philosophy of Transcendental idealist Kant came to reveal that the reason and experience is required by humans to understand and change the world.

\footnotetext{
James Garvey. (2006). The Twenty Greatest Philosophy Books (Translated by: CB.Mulyatno Pr.) Yogyakarta: Kanisius, p.157-171; Stephen Law. (2007). The Great Philosophers, Great Britain: Quercus, p. 177-187.
}

In other words, the Transcendental Idealist philosophy is built from a combination of rationalism and empiricism. ${ }^{7}$ Transcendental idealists believe that the use of reason will lead to the knowledge of world objects. While Empiricism is a school of philosophy that believes that knowledge comes from experience or observation of an object. ${ }^{8}$ For Immanuel Kant, rationalism and empiricism are the two things that actually separate from one another, but combined by Kant. This is what distinguishes it later with a view of Georg Wilhelm Friedrich Hegel, stating that Rationalism and Empiricism in fact is something that comes from the one center. In XX century, the system philosophy of Immanuel Kant was further developed by Neo-Kantian.

\section{Normativity Law in Perspective Thought of Hans Kelsen}

Followers Neo-Kantian philosophy in the field of law is Hans Kelsen. For Hans Kelsen, norm is a product of human thought that naturally deliberative. Something becomes a norm if it is desired to be the norm, that determination is based on morality and good values. So the considerations underlying a norm is meta-juridical. Something that is naturally meta-juridical is das sollen, and not become binding law society. In short for Hans Kelsen, legal norms always created through the will. These norms will be binding on the community if desired norms

Carsten Heidemann. (2004). "Hans Kelsen and the Transcendental Method." Northern Ireland Legal Quarterly, 55(4): 358.

8 Cecile Landau, Andrew Szudek, Sarah Tomley (ed). (2011). The Philosophy Book, London: Dorling Kindersley Limited, p. 165-171; James Garvey. (2006). The Twenty Greatest Philosophy Books, (Translation: CB Mulyatno Pr), Yogyakarta: Kanisius, p. 157-165. 
into law and should be set forth in a written form, issued by the competent authorities and load commands.

Kelsen's opinion indicates that legal positivism assumes moral conversation, values have been completed and final when it comes to the forming of positive law. Therefore, fragments of words that are well known from Hans Kelsen: the law obeyed not because it is considered a good or fair, but because the law was written and authorized by the authorities ${ }^{9}$. Hans Kelsen's thought is not really easy to learn, although containing arguments irrefutable. Thought of Hans Kelsen above is the substance of the Pure Theory of Law. The thought described above is actually one of his thought that exists in his works, The Pure Theory of Law drawn up in 1967.

Kelsen explanation starts from the way of thinking of Immanuel Kant, rather Hans Kelsen give substance to the way of thinking of Immanuel Kant, to later explain about the legal positivism. ${ }^{10}$ Immanuel Kant divides that life is divided into two (2) fields: the field of the facts and the ideal field. Firstly, the field of the facts (the real world) actually contains causal relationships that just happen, and it would happen like that. In this case, can be exemplified, in the event that the person threatened to give up something, he'll give. In nature, this fact can not be said when someone is forced to surrender something he should give. Secondly, the ideal field could be sourced from the mind

\footnotetext{
9 Hans Kelsen. (2009). What is Justice? Justice,Politic, and Law in the Mirror of Science. (Translated by: Nurulita Yusron). Bandung: Nusa Media, p. 316-322.

10 Kendra Frew. (2013). "Hans Kelsen's Theory and The Key to His Normativist Dimension." The Western Australian Jurist Journal, 4: 285-293.
}

based on the values, teachings. Thus, in the conception of this field could be illustrated, if someone threatened to give up something that he should not give. Meaning "he should not give it" depends on the will. However, according to Hans Kelsen, the will is not the will of the psychological. The will, according to Hans Kelsen is the will of neutral, objective and wills are indeed common sense should be like that. So, the will not to give something, based on the consideration that by the general (common sense) are considered true. Why is assumed to be true, because it is based on a doctrine that is objectively true teachings example: one should not accept anything that was not his right.

Teachings of this objective, according to Hans Kelsen should be returned to the higher teaching, up to the most basic norms (grundnorm). Thus, the basic norm is something desired sourced from objectified desire. Just because an objectification of a common will, so the basic norm (grundnorm) are not immutable, and is required. Basic norms thus must be a source of positive law.

The most fundamental norms is not identical to the natural law, or is not something that comes from the natural law. As followers of legal positivism, clearly Hans Kelsen rejected the natural law. For Hans Kelsen, the natural law basis is causal relationships that are just happen. So the natural law is a law that exists in the system itself. Field of ideal is the area outside of the system itself, or outside of causal relationships. But it's something that is supposed to be able to be the norm if it is desired to collectively as the norms are adhered together, which then issued in the form of binding legislation 
(positive law). Sourced from Transcendental Idealist philosophy of Immanuel Kant that was then thought of Hans Kelsen in the perspective of philosophy then known as Positivism Idealists.

\section{CONCLUSION}

Normativity of law is the notion that wants to show that there is a quirk in the law that it is normative. The normativity comes from values that have been accepted, not as individual values but have been accepted as something that comes from common sense, that are required and have been objectified as a common will and be the basis for the making of norms. The values established based on the combination of idealist and empirical thoughts, adopted by the transcendental idealist philosophy of Immanuel Kant and developed by Hans Kelsen in filling the legal meaning.

Implication normativity in the science of law, then the law is a priori assessment, based on values. Objectified norms must be done through dialogue (communication) without coercion, democratic and respects diversity. Objectified norms also mean that the norms should belong to everyone. Hence, it is expected to the birth of a valid norm. Valid, in the sense that the norm has been born from the very process of upholding morality and togetherness that is expected to give a sense of justice for all.

\section{BIBLIOGRAPHY}

Carsten Heidemann. (2004). "Hans Kelsen and the Transcendental Method." Northern Ireland Legal Quarterly, 55(4): 358.
Catherine Kellogg. (1998). "The Messianic without Marxism: Derrida's Marx and the Question of Justice". Journal Cultural Values, 2(1): 51-69. Doi: http://dx.doi. org/10.1080/14797589809359287

Cecile Landau, Andrew Szudek, and Sarah Tomley (ed). (2011). The Philosophy Book, London: Dorling Kindersley Limited.

Francis Bacon. (1958). The Advancement of Learning. (Last reprinted). London: J.M Dent and Sons Ltd.

Hans Kelsen. (2009). What is Justice? Justice, Politic, and Law in the Mirror of Science. (Translated by: Nurulita Yusron). Bandung: Nusa Media.

James Garvey. (2006). The Twenty Greatest Philosophy Books (Translated by: CB. Mulyatno Pr.). Yogyakarta: Kanisius. James Garvey. (2006). The Twenty Greatest Philosophy Books, (Translation: CB. Mulyatno Pr), Yogyakarta: Kanisius.

Kendra Frew. (2013). “Hans Kelsen's Theory and The Key to His Normativist Dimension." The Western Australian Jurist Journal, 4: 285-293.

Paul Kleinman. (2013). Philosophy 101 from Plato and Socrates to Ethics and Metaphysics, an Essential Primer on the History of Thought, Massachuset: Adam Media.

Paulson, S. L. (1992). "The Neo-Kantian Dimension of Kelsen's Pure Theory of Law". Oxford Journal of Legal Studies, 12(3), 311-332.

Richard Osborne. (1991). Philosophy for Beginners. (Translated by: P. Hardono Hadi). Yogyakarta: Kanisius. 
Hasanuddin Law Review - Vol. 3 Issue 1, April (2017)

Stephen Law. (2007). The Great Philosophers. Great Britain: Quercus.

Theo Huijbers. (1982). Filsafat Hukum Dalam Lintasan Sejarah. Yogyakarta: Kanisius. 